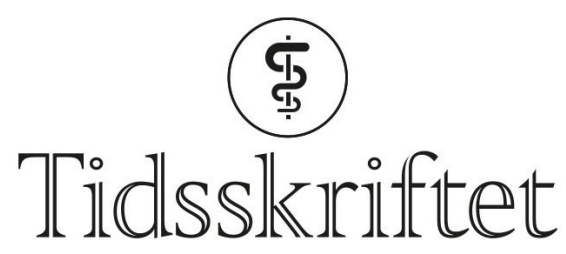

DEN NORSKE LEGEFORENING

\title{
Arne Bøyum
}

MINNEORD

HAAKON B. BENESTAD

OLE DIDRIK LAERUM

INGEBJØRG STORM-MATHISEN

JON STORM-MATHISEN

PER-KRISTIAN OPSTAD

ARILD NJÅ

HEGE B. FJERDINGSTAD

IREN SEFLAND

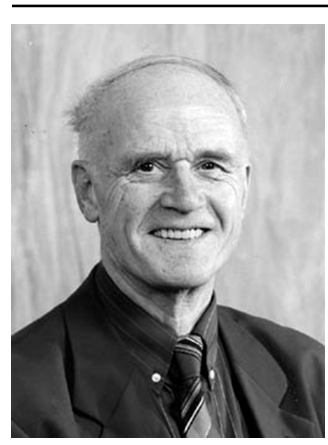

Arne Bøyum (4.4.1928-3.12.2018) var fødd på Voss og budde der og på Sandane i oppveksten. Sidan studerte han medisin i Bergen. Etter turnusteneste, militæret og ei tid i privatpraksis arbeidde han nokre år med hematologi på Rikshospitalet. Her vart interessa hans for forsking vekt, og frå 1961 arbeidde han på Forsvarets forskingsinstitutt (FFI) på Kjeller. Den gongen var det stor trong for meir kunnskap om følgjene av radioaktiv stråling og om å forbetra metodane for transplantasjon av beinmerg, som då var i startfasen.

Arne gjekk alltid grundig til verks med det han tok føre seg. Han tok doktorgraden ved Universitetet i Oslo i 1968 (arbeidet gjort ved FFI) etter å ha utvikla heilt nye metodar for separasjon av immunceller ved sedimentering og sentrifugering, fyrst for å fjerna lymfocyttar frå beinmerg som skulle brukast til transplantasjon, så til isolering av leukocyttar i blodet. Separasjonsvæskene inneheldt røntgenkontrastmidlet Isopaque frå 
Nycomed og eit karbohydrat, som dekstran eller fikoll. Blod- og strålingsforskarar over heile verda hadde vore på jakt etter slike metodar, og Verdas helseorganisasjon har no gjort desse til standard for korleis ein skulle isolera levande blodceller frå menneske. I åra som fylgde kom det tusenvis av artiklar over heile verda frå forskarar som hadde isolert blodceller «etter Bøyums metode». Etter kvart vart han den mest siterte forskaren i Noreg nokon gong, totalt 30 ooo siteringar då han nådde pensjonsalderen.

Allereie på 196o-talet byrja han å forska på stamceller i beinmergen og gjorde ei rekkje viktige oppdagingar. Arne var ein fin og logn sjef, kunnskapsrik og støttande. Fleire av hans tidlegare medarbeidarar vart seinare professorar og førte delar av forskinga hans vidare. Etter at Bøyum gjekk av med pensjon som 70-åring, flytta han til Institutt for medisinske basalfag ved Universitetet i Oslo. På Gaustad arbeidde han saman med ein av oss (HBB) i nærare to tiår. Heile tida publiserte han, den siste artikkelen då han var 86 år!

I god tradisjon heimanfrå nytta Arne nynorsk både privat og som fagmann. Han var ikkje berre eit arbeidsjern: Sportsmann, fjellvandrar, kåsør, kjøkemeister, musikant som song og spelte trekkspel og piano til, og ein gjestfri vert som innbaud vener til selskap med vossamat, aller helst pinnakjøt. Det er ikkje få gonger at me har opplevd på internasjonale kongressar at forskarar kjem bort til ein av oss og spør «Are you Norwegian? Do you know Dr. Bøyum?».

Me lyser fred over minnet hans.

Publisert: 25. februar 2019. Tidsskr Nor Legeforen. DOI: 10.4045/tidsskr.19.0003

(C) Tidsskrift for Den norske legeforening 2020. Lastet ned fra tidsskriftet.no 